\title{
Biblijska teologija krštenja u Duhu Svetome
}

\author{
Marko Juriček \\ Southwestern Baptist Theological Seminary \\ marko.juricek@gmail.com
}

UDK: 27-246:27-27:27-4:279.15

Stručni rad

https://doi.org/10.32862/k1.14.2.3

\section{Sažetak}

Ovaj članak bavit će se krštenjem u Duhu Svetome: što ono zapravo jest, kako se manifestira i koji su njegovi plodovi. U uvodu je prvo iznesena problematika i pitanja koja se vežu uz temu krštenja u Duhu, zajedno s tezom koja će biti testirana. Teza je da je krštenje u Duhu Svetome biblijski najrazumljivije ako se shvati kao jedinstven i neponovljiv događaj, svojstven svim kršćanima, a koji se događa u trenutku spasenja te da ga ne prate nikakvi trenutni i izvanjski znaci. U prvom su dijelu članka prezentirani različiti pogledi na doktrinu krštenja u Duhu Svetome i njihovi povijesni razvoji. Tada se prelazi na analizu biblijskih podataka, a u fokusu su svi glavni odjeljci koji se bave tom temom. Poseban je naglasak stavljen na knjigu Djela apostolskih i teologiju „drugog blagoslova”, koja se nalazi u središtu debate. Zatim se raspravlja o odnosu hermeneutike i iskustva. Konačno, u zaključku daje se praktičan pogled na krštenje u Duhu te biblijski poticaj na kršćanski život.

Ključne riječi: krštenje u Duhu Svetome, ispunjenje Duhom, Obećanje Očevo, odgodeni blagoslov, drugi blagoslov, naknadno/odvojeno iskustvo

“On će vas krstiti Duhom Svetim i ognjem..” $\left(M t 3,11^{b}\right)^{1}$

Postoji li „drugi blagoslov“ koji je moguće iskusiti nakon spasenja, kao što to tvrde pentekostalci? Ako postoji, može li se nazvati „krštenje u Duhu Svetome“ ili izjednačiti s njime? Što je zapravo krštenje u Duhu? Ovaj će članak na temelju

1 Ako nije drugačije navedeno, autor ovog članka koristit će ONLINE BIBLIJU - prijevod Biblije u izdanju Kršćanske sadašnjosti (https://biblija.ks.hr/default.aspx) 
analize biblijskog teksta pokazati da je krštenje u Duhu Svetom biblijski najrazumljivije ako se shvati kao jedinstven i neponovljiv događaj, svojstven svim kršćanima, a koji se događa u trenutku spasenja (kada je vjernik stavljen u Krista i postaje dio njegova tijela) te da ga ne prate nužno nikakvi trenutni i izvanjski znaci.

Najprije će biti predstavljeni različiti pogledi na doktrinu krštenja u Duhu, zajedno sa svojim povijesnim razvojem. Zatim će biti analiziran biblijski tekst, s fokusom na sve odjeljke koji su važni za ovu temu. Poseban će naglasak biti na knjizi Djela apostolskih i teologiji „drugog blagoslova“ koja je centralna za ispravno razumijevanje doktrine. Također, bit će razmatran odnos između iskustva i hermeneutike, tj. načina interpretacije i tumačenja Svetoga pisma. Konačno, bit će sagledana praktična primjena doktrine krštenja u Duhu zajedno s biblijskim poticajima na kršćanski život.

\section{Različiti pogledi i njihov povijesni razvoj}

Prije pentekostalnog probuđenja s početka devetnaestog stoljeća, doktrina o krštenju u Duhu Svetome nije bila nešto što bi izazivalo kontroverzu ili o čemu se redovito raspravljalo u Crkvi. No početkom dvadesetog stoljeća, a osobito nakon događaja u Crkvi u ulici Azusa i doživljaja koji su nazvani krštenje u Duhu, ta doktrina i iskustvo izvršili su značajan utjecaj na modernu Crkvu. Iskustvo krštenja u Duhu Svetome, popraćeno govorom u ,jezicima“, strelovito se proširilo različitim denominacijama, izazivajući uzbuđenje, rasprave, pa čak i nered. Danas postoji više različitih interpretacija o tome što se točno dogodilo prilikom toga „drugog pentekosta“. Ovisno o interpretaciji i razumijevanju tih događaja, razvili su se različiti pogledi na doktrinu krštenja u Duhu Svetome.

Postoji nekoliko glavnih pogleda na ovu kontroverznu doktrinu, a svaki pogled dalje se može podijeliti na određene varijante, ovisno o naglascima i razumijevanjima detalja. Glavna podjela bila bi na katolički i protestantski pristup. $S$ obzirom na to da se spomenuta doktrina nije previše razvijala (niti je imala prevelik utjecaj) unutar Pravoslavne crkve, njezin pristup neće biti evaluiran u ovome članku. Glavne podjele unutar protestantizma postoje između sakramentalnih (u anglikanskim, luteranskim i prezbiterijanskim krugovima) i nesakramentalnih pogleda (Medved 2015, 177). Budući da su ovu doktrinu donijeli pentekostalci razvojem svojih učenja i pentekostalnih denominacija, unutar samog protestantizma postoji još i podjela na tri glavne struje: evanđeosku, pentekostalnu i karizmatsku (Cheung 1996, 115). Neki autori također raspoznaju pet glavnih pogleda ili struja: katoličku, reformiranu, wesleyjevsku, pentekostalnu i karizmatsku (Brand 2004, 2). Ova šira podjela različitih pogleda iznesena je kronološkim redom, prema povijesnom vremenu nastanka i razvoja pojedinog 
pogleda. Stoga, ista će se podjela koristiti u prezentaciji svakoga pojedinog razumijevanja i njegovih specifičnosti.

Klasični je katolički pogled sakramentalne prirode, prema kojemu se spasenje i opravdanje razumijevaju kao međusobno isprepleteni i progresivni sakramentalni procesi. Oboje se inicijalno primaju kada vjernik prvi put prima sakrament, a kasnije postupno rastu u životu vjernika kroz daljnje participiranje u sakramentima (Horton 2004, 102). Što se tiče teološke pozicije Katoličke karizmatske obnove, koja je počela šezdesetih godina prošloga stoljeća, njezini pobornici bez zadrške priznaju da su usvojili klasičnu pentekostalnu doktrinu. S obzirom na to da „već razdvajaju djelo Duha Svetoga u sakramentima krštenja i svete potvrde (krizme), pitanje za njih nije razdvajanje samo po sebi, već 'kako da se to razdvajanje, kao novo iskustvo Duha uklopi u crkvenu sakramentalnu ekonomiju'“ (Horton 2004, 102). U teologiji katoličke karizmatske obnove „inicijalno izliće Duha Svetog u životu vjernika je istinsko i treba biti razlučeno od krštenja/obraćenja i naknadnih ispunjenja i pomazanja Duhom (Horton 2004, 103). Znači, općenito za katolike debata je ,je li krštenje u Duhu oslobađanje već postojeće sakramentalne milosti ili je to novo iskustvo, koje se dešava neovisno o sakramentima?" (Horton 2004, 102).

Do Reformacije, klasični katolički sakramentalni pogled krštenja u Duhu stajao je praktički neizazvan. No početkom Reformacije, razumijevanje spasenja i opravdanja počelo se mijenjati. Također, važnost sakramenata (i njihov broj) kao sredstava primanja milosti počela se umanjivati. Rane su protestantske denominacije gledale na spasenje kao na trenutni i cjeloviti događaj u trenutku kada je osoba povjerovala, dok se posvećenje shvaćalo kao nešto što se postiže postupno (progresivno). No kako Del Colle zaključuje, o krštenju u Duhu Svetome nije se, niti bi se raspravljalo „bez klasičnoga pentekostalnog doživljaja“ (Horton 2004, 101). Kao odgovor na tu današnji klasičnu pentekostalnu doktrinu, Kaiser predstavlja tipični reformirani pogled da se „krštenje u Duhu prima u trenutku kada se osoba obrati (Kaiser 2004, 16).

Da bi se, prije svega, steklo razumijevanje kako je došlo do pojave klasične pentekostalne doktrine krštenja u Duhu Svetom, potrebno se vratiti do osamnaestog stoljeća i pojave wesleyjanizma, ili takozvanog "kršćanskog savršenstva“. „Wesley je smatrao da je njegova misija obnoviti biblijski balans između opravdanja i posvećenja, balans koji je u katoličkoj tradiciji neravnomjerno naginjao posvećenju, a kod protestanata opravdanju“ (Dunning 2004, 182). Wesleyjevo razumijevanje djelovanja Duha Svetog prije svega se odnosilo na posvećenje, i za njega je milost imala dva značenja. Prvo je bilo nezaslužena naklonost, a drugo sila koja transformira (Dunning 2004, 186). Tu transformirajuću silu, koja posvećuje, Wesley je smatrao „drugim blagoslovom“ iako je nikada nije nazvao „krštenje u Duhu Svetome“. Njegov suradnik, Fletcher, taj je termin koristio češće iako ga nije poistovjećivao s kompletnim posvećenjem (Dunning 2004, 199). I to je upravo 
ono što je „pokret svetosti“ učinio u devetnaestom stoljeću. Vjernici pokreta svetosti poistovjetili su cijeli proces posvećenja s krštenjem u Duhu Svetome i koristili „Pentekost kao paradigmu za to 'drugo djelo milosti'“" (Dunning 2004, 199).

Ključni doktrinarni razvoj dogodio se kada je tradicionalni wesleyjanski naglasak na „savršenstvu“ spojen s temom „sile“. Phoebe Palmer izjednačila je ta dva termina, sugerirajući da "svetost jest sila“ (Dayton 1987, 94). Iz pokreta svetosti i dubljeg interesa za Duha Svetog, razvilo se pentekostalno probuđenje, također poznato pod imenom „prvi val“. To iskustvo i taj doživljaj interpretirani su i objašnjeni u terminima koji se danas nazivaju klasični pentekostalizam. Taj pokret objedinjuje tri temeljne značajke. Kao prvo, krštenje u Duhu je prije svega osnaživanje za kršćansku službu. Drugo, to iskustvo dolazi nakon spasenja i, treće, njegov je potvrdni znak govor u drugim jezicima (Loder 2002, 75-76).

Iz toga pokreta, $u$ drugom dijelu dvadesetoga stoljeća iznjedrio se karizmatski pokret („,drugi val“) s vlastitim razumijevanjima krštenja u Duhu. Unutar karizmatskog pokreta postoji lepeza pogleda i različitih stavova glede razdvojenosti doživljaja (krštenja u Duhu od spasenja) i nužnosti drugih jezika kao potvrdnog znaka. Takva je situacija karakteristična i za „treći val“. U trećem valu (naglasak je na ponovnom uspostavljanju službi apostola i proroka) objedinjujući čimbenik vezan uz krštenje u Duhu je manifestiranje znakova i čudesa, a poglavito darova Duha Svetog navedenih u listi iz 1. Korinćanima 12. poglavlje.

\section{Analiza biblijskih odjeljaka na kojima se temelji doktrina}

Sveukupno u Pismu postoji samo sedam odjeljaka u kojima se krštenje u Duhu Svetome spominje eksplicitno. Svi se nalaze u Novom zavjetu, od čega su četiri u evanđeljima (Mt 3,11, Mk 1,8, Lk 3,16, Iv 1,33), dva u Djelima apostolskim (Djela 1,$5 ; 11,16)$ te jedan u poslanicama $(1$. Kor 12,13$)$ i svaki je primjer u glagolskom obliku „krstiti/kršteni Duhom Svetim“. Unatoč tomu, kao pojam koji opisuje to iskustvo u moderna vremena razvijen je i uvrježeniji imenički oblik "krštenje Duhom" (Medved 2015, 173).

U šest slučajeva (osim u Markovu evanđelju) koristi se ista riječ u grčkom, priložna oznaka „en”. U Markovu evanđelju ta je priložna oznaka izostavljena, ,ali ne dolazi do promjene u značenju, jer imenica u dativu sama može imati isti smisao kao i kada se koristi sa priložnom oznakom 'en' (Grudem 2000, 767). Ta priložna oznaka može se prevesti kao „od, u, sa ili po“. Prvih šest puta kada se spominje (u Evanđeljima i Djelima) radi se o usporedbi s Ivanovim vodenim krštenjem, i gotovo uvijek je prevedena kao „u ili sa“ (u hrvatskom prijevodu ta priložna oznaka najčešće ostaje neizrečena). U slučaju 1 . Korinćanima 12,13 , većina modernih prijevoda, prevodi je kao „s/sa“ (Grudem 2000, 768) i za pobornike „teologije drugog blagoslova“ zadnji dio toga retka ima potpuno drugačiji smisao nego u prethodnih šest slučajeva. 


\subsection{Krštenje u Duhu Svetom u Starom zavjetu}

Kada se pristupa ovoj temi u Starome zavjetu, nailazi se na jedan očigledan problem. Naime, kako je uopće moguće razgovarati o krštenju Duhom kada se taj pojam ne spominje u Starom zavjetu? U ovom je slučaju potrebno upotrijebiti određene hermeneutičke principe. To su alati i objektivne (mjerljive) metode koje se koriste u interpretaciji Pisma, kako bi se došlo do njegova boljeg razumijevanja. Za kršćane, progresivno (napredujuće ili rastuće) otkrivenje, tj. uvjerenje da se Bog progresivno objavljuje kroz Pismo, bit će vrlo korisno u ovome primjeru. Drugim riječima, to je razumijevanje da je u Starom zavjetu Novi zavjet prikriven, dok je u Novom zavjetu, Stari zavjet otkriven. Ovo razumijevanje i interpretacija jasno se vidi u mnogim Isusovim novozavjetnim izjavama. Tako, kada Isus govori o krštenju u Duhu Svetom, kaže svojim učenicima „neka čekaju Obećanje Očevo ... Ivan je krstio vodom, a vi ćete naskoro nakon ovih dana biti kršteni Duhom Svetim'“ (Dj 1,4-5).

Isusovo direktno podsjećanje na „Obećanje Očevo" daje zaključiti da je to obećanje nekada ranije moralo biti i dano, a to je, prema svemu sudeći, u Starom zavjetu. Za one koji se ne slažu s takvim zaključkom, već predlažu da se to obećanje odnosi na Isusove vlastite riječi dane u Novom zavjetu, apostol Petar nudi jasnu potvrdu u svojoj poruci na Pentekost (Dj 2,16-18). U njoj objašnjava da je ono što se dogodilo na Pentekost, barem djelomično (ili inicijalno) ispunjenje proroštva o obećanom izliću Duha Svetog koje je dao prorok Joel (Joel 2). Na ovom primjeru vidi se da je u Novom zavjetu otvoreno obznanjeno nešto što je bilo barem implicitno objavljeno u Starome. S novozavjetnim razumijevanjem krštenja u Duhu (kao što će biti prezentirano), lako će biti uspostaviti poveznicu između novozavjetnih i starozavjetnih odjeljaka. Primjer je Mojsijev vapaj u Knjizi Brojeva: "Oh, kad bi sav narod Jahvin postao prorok! Kad bi Jahve na njih izlio svoga duha!“ (Br 11,29). Da to nije bila isključivo Mojsijeva želja, već i želja koje je dolazila iz samog Božjega srca, jasno je vidljivo iz Joela 2, Ezekiela 36 i Jeremije 31. Obećanje, Dar i Duh, svi upućuju na istu stvar - Novi savez koji je obećao Bog Otac, a uspostavio Bog Sin.

\subsection{Krštenje u Duhu Svetom u Evanđeljima}

Kao što je već rečeno, krštenje u Duhu spominje se u sva četiri evanđelja: Matej 3,11-12, Marko 1,8, Luka 3,16-17 i Ivan 1,33. Ivan Krstitelj objavljuje, a Matej i Luka dodaju u svojim izvještajima da će Mesija krstiti, ne samo Duhom Svetim već i vatrom. Ovo krštenje vatrom često se povezuje sa sudom s obzirom da ga vatra često predstavlja u Starom zavjetu (Kaiser 2004, 300). ${ }^{2}$ Da se ovo krštenje

2 To nije jedina poveznica jer vatra također može imati i pročišćavajući učinak, kao na primjer u Izaiji 4,4. 
vatrom ne odnosi na neko posebno i izdvojeno krštenje, već na plamene jezike krštenja u Duhu Svetome, očito je iz događaja zabilježenih na Pentekost. Što se dalje tiče primjera iz Evanđelja, važno je primijetiti „da je glagol u aktivnom obliku, a Krist je subjekt" (Kaiser 2004, 20).

Odlomak iz Ivana 20,21-22, koji je također poznat pod nazivom „Ivanov Pentekost", prvo je mjesto gdje se pojavljuju značajnije razlike među interpretacijama. Za Williamsa (1990, 2:174), to je vrijeme i mjesto kada su učenici rođeni od Duha. Arrington $(1981,5)$ se slaže i dodaje da je „prisilna egzegeza“ pretpostaviti da učenici nisu bili nanovorođeni prije Pentekosta. Znači, prema njima, na dan Pentekosta Duh se Sveti spustio na učenike koji su već bili „novorođena zajednica vjernih“ (Williams 1990, 2:174). Iako je ovo razumijevanje svih klasičnih pentekostalaca i nekih karizmatika, postoje određeni problemi u spomenutoj interpretaciji. Ti problemi tiču se razumijevanja krštenja u Duhu kao „drugog blagoslova", tj. događaja koji je odvojen od spasenja i događa se naknadno. Autor ovoga članka vidi uvjerljiviji način za slaganje različitih dijelova Pisma u jednu kompaktnu cjelinu. Ako umjesto „drugog blagoslova“ primijenimo koncept „odgođenog blagoslova“, sastavljana cjelina i dobivena slika bit će mnogo jasnija.

Grudem predlaže da „Ivanov Pentekost“ trebamo shvatiti kao „proročki čin“. Iako na prvu pomisao takva interpretacija djeluje čudno, kada se uzme u obzir Ivan 7,38-393, ovaj prijedlog postaje vrlo vjerodostojan. Redak 39 također upućuje na određeni protok vremena: „to reče o Duhu kojega su imali primiti oni što vjeruju“. Što se tiče toga vremenskog odmaka, umjesto da se primanje Duha smatra naknadnim ili razdvojenim od spasenja, ispravnije ga je smatrati odgođenim događajem. Takvo razumijevanje igrat će važnu ulogu prilikom interpretacije događaja u knjizi Djela apostolskih. Dodatni razlog za takav pristup je također da se ne bi dovodilo u pitanje novozavjetno spasenje i evanđelje milosti, koje je namijenjeno svima onima ,što vjeruju“. Ta slika savršeno pristaje događajima opisanima u Djelima 2 na dan Pentekosta. Onima koji su vjerovali u njega (učenici), na taj su dan primili Duha Svetoga, ušli u novozavjetno iskustvo spasenja i postali dio tijela Kristova, tj. Crkve. ${ }^{4}$

3 "Neka pije koji vjeruje u mene! Kao što reče Pismo: 'Rijeke će žive vode poteći iz njegove utrobe!' To reče o Duhu kojega su imali primiti oni što vjeruju u njega. Tada doista ne bijaše još došao Duh jer Isus nije bio proslavljen."

4 Ako se Isusovo proslavljenje (Iv 7,39) odnosi samo na Isusovo uskrslo i proslavljeno tijelo i na „primanje Duha Svetoga“ u Ivanu 20,22 kao ispunjenje Ivana 7, što onda treba biti ispunjeno na dan Pentekosta? Nasuprot takvoj interpretaciji, Petar kaže da je Obećanje Očevo, Duh Sveti, primljen i izliven od strane uznesenog Krista koji je „desnicom dakle Božjom uzvišen“ (Dj 2,33). ESV prijevod glasi „uzvišen s desne strane Bogu“, gdje je još jasnije opisana pozicija autoriteta i uzvišenja (proslavljenja) koju je primio Krist. 


\subsection{Krštenje u Duhu Svetom u Djelima apostolskim}

Da bi se ispravno razumjela doktrina krštenja u Duhu, ključno je razumjeti kontekst u kojem su nastala Djela apostolska, čije razumijevanje ovisi o hermeneutičkom pristupu koji se primjenjuje. Iako među pobornicima gramatičko-povijesne metode postoji generalni konsenzus i prepoznavanje da su Djela apostolska povijesni narativ, kako primijeniti taj specifični književni stil (žanr) središte je debate između evanđeoskih kršćana i klasičnih pentekostalaca. ${ }^{5}$ Jesu li Djela apostolska samo „opis“ ili su i „propis“? Mogu li se i smiju li se izvlačiti teološki zaključci iz žanra povijesnog narativa ili je to dopušteno samo za didaktične (poučne) dijelove Pisma, kao što su poslanice? Koliko su različite i razdvojene Lukina pneumatologija od Pavlove (Dunn 1993, 27)?

Dan Pentekosta u Djelima 2 opisuje izliće Duha Svetog kao ključni događaj u novozavjetnom razdoblju (Dunn 1993, 16). U ovom članku već je položen dio temelja za taj događaj: Bog Otac dao je Obećanje Svoga Duha u Starome zavjetu. Na početku Novog zavjeta Ivan Krstitelj prepoznaje Isusa kao onoga koji krštava Duhom Svetim. Također, Luka, autor Djela apostolskih, ponovno to naglašava na početku svoje knjige. U Djelima 1,4-5 navodi Obećanje Očevo da će učenici biti kršteni (u ili sa) Duhom Svetim. Posljedica toga bit će: “... primit ćete snagu Duha Svetoga koji će sići na vas i bit ćete mi svjedoci u Jeruzalemu, po svoj Judeji i Samariji i sve do kraja zemlje“ (Dj 1,8). Ovaj redak služi kao plan i kostur knjige jer je Luka prema tom retku strukturirao cijelu knjigu. Pažljivim čitanjem Djela apostolskih, osoba može uočiti da su Obećanje, krštenje Duhom Svetim i osnaženje za službu svi dijelovi jednog te istog dara (Unger 1944, 242).

\subsubsection{Djela 2, "Jeruzalemski pentekost“}

Iako pojam „krštenje u Duhu“ nije izravno korišten u odjeljku Djela 2,1-4, očito je da je dan Pentekosta bio ispunjenje dugoočekivanog „Obećanja Očevog“. Svih sto dvadeset učenika „se napuniše Duha Svetoga“ (redak 4), kao znak da je Duh obećan po proroku Joelu konačno izliven na svako tijelo (redak 17). To je bila izravna posljedica Mesijina uzvišenja. „Desnicom dakle Božjom uzvišen, primio je od Oca Obećanje, Duha Svetoga, i izlio ga kako i sami gledate i slušate“ (Dj 2,33). Petar je sve prisutne poticao da se pokaju i da se krste u Mesijino ime, za oproštenje grijeha kako bi mogli primiti „dar, Duha Svetoga“ (r. 38). „Ta za vas je ovo obećanje i za djecu vašu i za sve one izdaleka, koje pozove Gospodin Bog naš“ (r. 39).

5 Klasični pentekostalci su također poznati pod već spomenutim nazivom „prvi val“. Za razliku od SAD-a, u Hrvatskoj podjela na pentekostalce i evanđeoske kršćane nema toliko praktičnu primjenu budući da se glavnina pentekostalaca nalazi u najvećoj pentekostalnoj denominaciji pod imenom Evanđeosko-pentekostna crkva (EPC). 
Ako je razumijevanje ovoga događaja ograničeno samo na „osnaživanje za službu“, i to kao iskustvo „nakon i odvojeno“ od iskustva spasenja, tada se rađaju mnoga nova pitanja. Kada je Crkva nastala ako ne na Pentekost? Ako je Novi savez uspostavljen prilikom Posljednje večere, kada je onda potvrđen (ratificiran)? I kojim znacima? Slijedeći takvo tumačenje, osoba bi morala zanemariti spasonosno djelovanje Duha Svetog jer bi se onda sva dana obećanja odnosila samo na osnaživanje. Ovdje nije u pitanju samo naglasak Lukine pneumatologije u odnosu na Pavlovu već što se nalazi u centru Evanđelja? Čak da to i jest osnaživanje, zasigurno ono nije odvojeno od spasenja! Uvjerljivije, ovaj događaj (Pentekost) predstavlja ulazak učenika u puninu novozavjetnog spasenja koje su čekali (Iv 7,39).

\subsubsection{Djela 8, „Samaritanski pentekost“}

Prema rasporedu danom u Djelima 1,8, Evanđelje je napravilo svoj prvi proboj izvan granica Judeje. U Samariji je Filip propovijedao Krista, i to je propovijedanje bilo popraćeno znacima, istjerivanjem demona i iscjeljenjima. „Ali kad povjerovaše Filipu koji navješćivaše evanđelje o kraljevstvu Božjemu i o imenu Isusa Krista, krštavahu se - muževi i žene“ (Dj 8,12). Petar i Ivan bili su poslani da mole za Samaritance kako bi primili Duha Svetog jer se to još nije dogodilo. ${ }^{6}$

$S$ obzirom na to da ne postoji očitih razloga zašto bi se sumnjalo u njihovu vjeru (Samarija je prigrlila riječ Božju u Dj 8,14), za klasične pentekostalce ovaj je odjeljak čvrsti oslonac za teologiju ,drugog blagoslova“. Prema njihovu razumijevanju, Samaritanci su bili spašeni u trenutku kada su povjerovali, a sada „nakon “ što su bili spašeni, primaju krštenje u Duhu Svetom. No potrebno je upitati se zbog kojih razloga autor Luka opisuje taj događaj na takav način? Želi li uputiti čitatelja na to da je u pitanju događaj koji slijedi nakon spasenja kako bi uspostavio obrazac za „drugi blagoslov“? Ili, želi pokazati ovu situaciju kao anomaliju? $\mathrm{Na}$ to je pitanje nemoguće odgovoriti bez gledanja na kontekst, kako povijesni tako i neposredni.

Razumijevajući povijest neprijateljstva između Samaritanaca i Židova daje Bogu „opravdan razlog“ da uskrati davanje Duha Samaritancima. Možda je Božja namjera bila baš ta da potvrdi da su i Samaritanci među pozvanima (Dj 2,39) i dodani njihovu broju (Dj 2,47)? Dajući Samaritancima Duha Svetoga specifično kroz polaganje ruku židovskih apostola iz Jeruzalema, Bog je mogao ispuniti dvostruku svrhu. Pokazao je Samaritancima da se u Jeruzalemu nalazi pravi Hram iz

6 "Kad su apostoli u Jeruzalemu čuli da je Samarija prigrlila riječ Božju, poslaše k njima Petra i Ivana. Oni siđoše i pomoliše se za njih da bi primili Duha Svetoga. Jer još ni na koga od njih ne bijaše sišao; bijahu samo kršteni u ime Gospodina Isusa. Tada polagahu ruke na njih i oni primahu Duha Svetoga" (Dj 8,14-17). 
kojeg dolaze Duh i istina (Iv 4). Također, pokazao je i apostolima da su i „samaritanski psi“" primili Duha Svetoga, jer je to potvrdio vidljivim znacima (Dj 8,18), te da su i oni sada braća po vjeri. Ovakva interpretacija događaja u povijesnom kontekstu (specifičnom i unikatnom vremenu u povijesti spasenja), dodatno je potvrđena i tekstualnim kontekstom. Umjesto da opiše ovaj događaj (krštenje u Duhu) kao nešto što je uslijedilo nakon spasenja Samaritanaca, apostol Petar ga povezuje sa spasenjem i Evanđeljem milosti, nazivajući taj događaj primanja Duha Svetoga „dar Božji“ (Dj 8,20).

\subsubsection{Djela 9, „Savlovo (Pavlovo) obraćenje“}

Obraćenje apostola Pavla (Savla) u Djelima 9 još je jedan zabilježen primjer odgođenog (a ne naknadnog ili ponovnog) primanja Duha Svetog. Iz teksta se logično može zaključiti da je iskustvo na putu za Damask (r. 3-8) vrijeme i mjesto kada je Pavao prvi put uzvjerovao u Isusa. Kako onda objasniti činjenicu da je Ananija položio svoje ruke na njega da progleda „, napuni se Duha Svetoga“ (r. 17)? Je li ovo dokaz razlučivanja između Pavlova spasenja i krštenja u Duhu Svetom? Pobornici tog uvjerenja nalaze dodatnu potvrdu u činjenici da mu se čak i Ananija obraća kao „bratu Savlu“ (r. 17). No s obzirom na to da knjiga Djela apostolskih opisuje posebno vrijeme u povijesti spasenja, postoji i drugo, manje problematično, objašnjenje koje je ne samo moguće već i vjerojatno. Uzevši u obzir da je sve do sada Pavao progonio Crkvu, zasigurno nije bilo lako za njega postati prihvaćenim od strane vjernika. ${ }^{7}$ Čak se i pobožni Ananija nećkao poslušati direktnu uputu uskrsloga Gospodina da ide i položi svoje ruke na Pavla (r. 10-16). Na taj način, kao i sa Samaritancima, predrasude su trebale biti slomljene da bi Tijelo Kristovo moglo nastaviti rasti i „sačuvati jedinstvo Duha svezom mira!“ (Ef 4,3).

\subsubsection{Djela 10, „Poganski pentekost“}

Širenje Evanđelja „do kraja zemlje“ prema predlošku danom na početku knjige Djela apostolskih $(1,8)$ nije definirano samo zemljopisno, već se odnosi i na micanje nacionalnih i rasnih granica (predrasuda). To se jasno može vidjeti na više mjesta (Dj 2,39; 9,15; 10,28).

I upravo to je ono što Luka opisuje u Djelima 10 kada Evanđelje doseže do pogana. Na stranu sva Kornelijeva dobra djela i pravednost (r. 2, 22, 31, 35), njemu je i dalje trebala biti propovijedana poruka spasenja po kojoj će se spasiti on i cijelo njegovo kućanstvo $(11,14)$. Tu je poruku propovijedao Petar govoreći o Isusovoj službi, smrti i uskrsnuću (10,37-42). Dok je Petar još dijelio Evanđelje „da tko god u nj [Isusa] vjeruje, po imenu njegovu prima oproštenje grijeha"(r. 43), prekinuo

7 "Kad je Savao došao u Jeruzalem, gledao se pridružiti učenicima, ali ga se svi bojahu: nisu vjerovali da je učenik" (Dj 9,26). 
ga je Duh Sveti. I „siđe Duh Sveti na sve koji su slušali tu besjedu“ (r. 44), a svi vjernici iz obrezanja su se čudili „što se i na pogane izlio dar Duha Svetoga“ (r. 45).

Kada je Petar potvrdio da su i pogani primili Duha Svetog, baš kao i apostoli i ostali učenici na dan Pentekosta (10,47 i 11,15), je li on potvrđivao i utvrđivao da je krštenje u Duhu razdvojeno od spasenja? Iako je moguće osporavati ponuđene razloge i objašnjene za „odgođeno“ krštenje u Duhu Svetom u Djelima 2 i 8, ovdje ne postoji niti tračak odgode u tekstu. Upravo suprotno, Luka čvrsto utvrđuje „prvi blagoslov“. Pogani „primiše riječ Božju“ $(11,1)$ i Bog im „dade obraćenje na život!“ $(11,18)$. I još jednom Petar podsjeća na to da je upravo tako bilo $\mathrm{i}, \mathrm{u}$ početku“ ${ }^{8}{ }^{8}$ Ovaj je silazak Duha Svetog na pogane izjednačio s ispunjenjem Duha koji su učenici iskusili na Pentekost, a oba je ta događaja pak nazvao Isusovim obećanjem da će biti kršteni Duhom Svetim. To je dar koji primaju oni koji povjeruju! Koji drugi blagoslov može biti ovdje u pitanju, doli blagoslov vjerovanja u Evanđelje i spasenja?

\subsubsection{Djela 19, „Učenici u Efezu“}

Da bi se došlo do interpretacije ovoga odjeljka, potrebno je savladati dvije prepreke. Prva se odnosi na to što Luka naziva dvanaestoricu ljudi mathētas "učenici". Neki su pokušali iskoristiti specifičnu nedorečenost toga pojma „učenici“ kao da se odnosi na ljude koji su spašeni, a zatim njihovo primanje Duha Svetog kao iskustvo „drugog blagoslova“. Iz konteksta priče jasno je da je Pavao u ovom slučaju susreo učenike Ivana Krstitelja. „Činjenica da je ovo jedini primjer ponovnog krštenja u Novom zavjetu sugerira da su 'učenici' u Efezu bili jedinstven slučaj“ (Loder 2002, 85).

Drugi pak izazov u ovom odjeljku je Pavlovo pitanje: „Jeste li primili Duha Svetoga kad ste povjerovali?"“ (Dj 19,2) Postoji debata kako bi se trebalo prevesti glagolski aorist elabete (primili) i njegov particip pisteusantes (kad ste povjerovali). Unger (1944a, 491) kaže da je ispravnije povezati ih s „,kad“ nego „nakon“ jer oni označavaju ,simultanu akciju“. ${ }^{9}$ Neki su predložili da je Pavao vidio da nešto nije u redu s njihovom vjerom. A odgovor učenika: „Ta ni čuli nismo da ima Duh Sveti.“(r. 2) uistinu potvrđuje da je nešto nedostajalo. Drugi razlog za Pavlovo pitanje može biti zbog njegove svjesnosti da postoji mogućnost „odgode“ primanja Duha Svetog, kao što je i on sam doživio u Djelima 9, a i Samaritanci u Djelima

8 „I kad počeh govoriti, siđe na njih Duh Sveti kao ono na nas u početku. Sjetih se tada riječi Gospodnje: 'Ivan je', govoraše on, 'krstio vodom, a vi ćete biti kršteni Duhom Svetim.' Ako im je dakle Bog dao isti dar kao i nama koji povjerovasmo u Gospodina Isusa Krista, tko sam ja da bih se smio oprijeti Bogu" (Dj 11,15-17).

9 „Uzevši u obzir da je ova sintaktička konstrukcija (prošli priložni particip) vrlo fleksibilna te da kontekst ne nudi rješenje za ovu nedoumicu, ostaje na teološkom uvjerenju da odredi kako prevesti ovu konstrukciju." 
8. Kada im je objasnio da je Ivan Krstitelj govorio ljudima da vjeruju u Isusa (r. 4), učenici su pristali krstiti se u Isusovo ime (r. 5) te su tako izrazili svoju vjeru u njega. Zanimljivo je da je tada Pavao učinio istu stvar koju su uradili drugi (Petar i Ivan u Dj 8 te Ananija u Dj 9) u slučajevima „odgođenog” primanja Duha: položio je ruke na njih kako bi i oni primili Duha Svetoga. ${ }^{10}$

Što to Luka želi komunicirati ovdje? Ovaj Pavlov susret s „učenicima“ u Efezu je značajan i interesantan iz više razloga. Iako Efez nije „kraj zemlje“ (Dj 1,8) pa čak niti tada poznatog teritorija, barem se nalazi izvan zemljopisnih granica Izraela. Možda je to razlog da je Luka odlučio zabilježiti ovaj događaj koji se dogodio mnogo godina nakon Pentekosta. Ferguson pak daje prijedlog koji konkretnije pristaje ovaj situaciji: „Kao i prvi učenici na Pentekost, od kojih su mnogi primili Ivanovo krštenje, tako su se i ova dvanaestorica učenika nalazila u tranziciji iz doba iščekivanja do doba ispunjena" (Loder 2002, 85-86).

\subsection{Djela apostolska, „Zaključak“}

Prije svega, nema dvojbe da Luka nije bio samo liječnik već zasigurno i povjesničar i teolog. Iako u svojim djelima (Evanđelje po Luki i Djela apostolska) naglašava službu (djelovanje i osnaživanje) Duha Svetoga, njegova pneumatologija nije potpuno različita ili odvojena od Pavlove. I on se bavi spasonosnim djelovanjem Duha Svetog, kao što se i Pavao bavi karizmatskim manifestacijama Duha. Činjenica je da za razliku od njega Pavlov naglasak uistinu jest na objašnjenju spasonosnog djelovanja Duha (Dunn 1993, 27).

Kao drugo, ako je Luka želio uspostaviti jasan obrazac primanja Duha Svetog i dati teološki dokaz za postojanje „drugog blagoslova”, zaista je to učinio vrlo loše. Tabela koju je sastavio Loder $(2002,87)$ jasno prezentira da ni jedan od pet zabilježenih događaja nije identičan drugome.

\begin{tabular}{|c|c|c|c|c|c|c|}
\hline ODJELJAK & $\begin{array}{c}\text { POVIJESNA } \\
\text { SITUACIJA }\end{array}$ & $\begin{array}{c}\text { GRUPA } \\
\text { LJUDI }\end{array}$ & $\begin{array}{c}\text { ZNAK } \\
\text { (OVI) }\end{array}$ & MOLITVA & $\begin{array}{c}\text { POLAGA- } \\
\text { NJE } \\
\text { RUKU }\end{array}$ & $\begin{array}{c}\text { VODENO } \\
\text { KRŠTENJE }\end{array}$ \\
\hline Djela 2 & $\begin{array}{c}\text { Pentekost, } \\
\text { početno } \\
\text { izliće Duha }\end{array}$ & $\begin{array}{c}\text { Isusovi } \\
\text { učenici iz } \\
\text { Židovstva }\end{array}$ & $\begin{array}{c}\text { Zvuk vjetra, } \\
\text { plameni } \\
\text { jezici, jezici i } \\
\text { veličanje }\end{array}$ & Da & $\mathrm{Ne}$ & $\mathrm{Ne}$ \\
\hline Djela 8 & $\begin{array}{c}\text { Širenje } \\
\text { Evanđelja u } \\
\text { Samariju }\end{array}$ & $\begin{array}{c}\text { Samaritan- } \\
\text { ski } \\
\text { „vjernici“ }\end{array}$ & $\begin{array}{c}\text { Nisu } \\
\text { spomenuti }{ }^{1}\end{array}$ & $\mathrm{Da}$ & $\mathrm{Da}$ & $\begin{array}{c}\text { Da, prije } \\
\text { primanja } \\
\text { Duha }\end{array}$ \\
\hline
\end{tabular}

10 “... pa kad Pavao položi na njih ruke, dođe Duh Sveti na njih te stanu govoriti drugim jezicima i prorokovati” (Dj 19,6). 


\begin{tabular}{|c|c|c|c|c|c|c|}
\hline Djela 9 & $\begin{array}{c}\text { Pavlovo } \\
\text { obraćenje }\end{array}$ & $\begin{array}{c}\text { Savao/ } \\
\text { Pavao }\end{array}$ & $\begin{array}{c}\text { Nisu } \\
\text { spomenuti }\end{array}$ & Da & Da & $\begin{array}{c}\text { Da, nakon } \\
\text { primanja } \\
\text { Duha }\end{array}$ \\
\hline Djela 10 & $\begin{array}{c}\text { Šrenje } \\
\text { Evanđelja } \\
\text { poganima }\end{array}$ & $\begin{array}{c}\text { Bogoboja- } \\
\text { zni pogani }\end{array}$ & $\begin{array}{c}\text { Jezici i } \\
\text { veličanje }\end{array}$ & $\mathrm{Ne}$ & $\begin{array}{c}\text { Da, nakon } \\
\text { primanja } \\
\text { Duha }\end{array}$ \\
\hline Djela 19 & $\begin{array}{c}\text { Ispunjenje } \\
\text { službe Ivana } \\
\text { Krstitelja }\end{array}$ & $\begin{array}{c}\text { "Učenici“ } \\
\text { Ivana } \\
\text { Krstitelja }\end{array}$ & $\begin{array}{c}\text { Jezici i } \\
\text { proroštvo }\end{array}$ & $\mathrm{Ne}$ & $\mathrm{Da}$ & $\begin{array}{c}\text { Da, nakon } \\
\text { primanja } \\
\text { Duha }\end{array}$ \\
\hline
\end{tabular}

Analizom svih pet zabilježenih slučajeva uočava se da ne postoji dokaz da Luka u Djelima želi prezentirati jasno učenje ili uspostaviti mjerilo kršćanskog iskustva. Također, očito je da ovi događaji nemaju određeni uzorak, a još manje da predstavljaju pravilo ili normativ (Loder 2002, 88).

Postoji još jedna zanimljiva tema koja se provlači kroz knjigu Djela apostolskih. Ona je osobito značajna za odgođeno (a ne ponovno) iskustvo primanja Duha Svetog samaritanskih vjernika, tj. za njihovo iskustvo spasenja. Radi se, naime, o „ključevima Kraljevstva nebeskog”. U Mateju 16, nakon što je Petar objavio da Isus jest Mesija, Isus mu „predaje“ ključeve Kraljevstva nebeskog. Čudesno je zatim vidjeti u Djelima apostolskim kako Bog zaista i koristi te ključeve (Petra) kako bi otključao svoje Kraljevstvo onima koji vjeruju, ponajprije Židovima (Dj 2), zatim miješanim Samaritancima ( $\mathrm{Dj} 8$ ), a konačno i punokrvnim poganima (Dj 10)! (Unger 1944a, 488).

\subsection{Krštenje u Duhu Svetom u poslanicama}

Kao što je već spomenuto, postoji samo jedan spomen krštenja u Duhu Svetom u poslanicama, a to je u 1 . Korinćanima $12,13 .{ }^{11}$ Ovdje se u središtu debate nalazi prijevod grčkog prijedloga "en" u izrazu en heni Pneumati "u jednom Duhu". U ostalih šest mjesta, gdje se spominje krštenje u Duhu, očito je Isus agent koji krštava, a Duh Sveti je element (osoba) u koji (koga) se netko krštava. U ovom slučaju, ako se prijedlog en prevede „s/sa ili po“, to znači da je Duh Sveti postao agent. Ovo je interpretacija za koju se zalažu pobornici teologije "drugog blagoslova“. Ako je njihovo tumačenje ispravno, onda se ovaj izraz treba shvatiti kao krštenje koje čini Duh Sveti, i nešto što je potpuno odvojeno i drugačije od krštenja koje čini Isus na preostalih šest spomenutih mjesta. Evanđeoski prijevod prijedloga s „u“ uklanja razliku između tih krštenja, ali ostavlja nejasnoću jer u tom slučaju neizrečeni agent (Krist) krštava vjernike u Duhu Svetom, u vlastito tijelo. ${ }^{12}$ Iako

11 “Ta u jednom Duhu svi smo u jedno tijelo kršteni, bilo Židovi, bilo Grci, bilo robovi, bilo slobodni. I svi smo jednim Duhom napojeni."

12 U originalu članak je napisan na engleskom jeziku i u ovom kontekstu bavi se problematikom engleskih prijevoda, što nije nužno u potpunosti primjenjivo na hrvatske prijevode. 
se prva interpretacija (,s/sa ili po“) čini stabilnijom, ne znači da ona nužno vodi u doktrinu „naknadnog ili ponovnog" blagoslova, odvojenog od spasenja. Može se odnositi na različite faze u redoslijedu spasenja (Grudem 2000, 670). Kako Duh Sveti nastanjuje (nanovo rađa) vjernika i krštava ga u Krista (kao dio njegova tijela, Crkve), u isto vrijeme Krist krštava vjernika Duhom Svetim (obećanje Ivana Krstitelja) i nastanjuje se u njemu (po Duhu Svetom) (Unger 1944, 233-35). Iako je jedinstvo između Boga i čovjeka nerazjašnjiva misterija, Crkva je i dalje treba nastojati objasniti što ljudski moguće jasnije i jednostavnije.

\section{Odnos hermeneutike prema iskustvu i znacima}

Kršćanstvo nije samo skup doktrina koje zahtijevaju razumsko prihvaćanje. Ono je također i religija iskustva srca. Jednako tako dani su nam i Riječ Božja i Duh Božji. Teologija je samo ljudsko nastojanje u razumijevanju obojega, i to je do određene mjere moguće. No postoje i ograničenja, kako u razumijevanju Riječi Božje tako još više i u razumijevanju Duha Božjega.

Kako onda da rasuđujemo iskustva i događaje koji se pripisuju Duhu Božjemu? Tako da se vraćamo na temelj Riječi Božje i tumačimo je koristeći ispravne hermeneutičke alate koji nam stoje na raspolaganju. Na taj način osoba može testirati svoje doživljaje i vidjeti kako i da li se slažu sa svjedočanstvom koje daje Riječ. I nije ništa krivo u nastojanju razvijanja sustava doktrine ili učenja koji je u skladu s ostatkom Pisma, sve dok se za to koriste objektivne metode interpretacije. No ako subjektivna iskustva postanu glavno mjerilo, tada se brišu granice objektivnosti i sve postaje dopušteno kako bi se nešto potvrdilo ili opravdalo. Ovaj autor smatra da je to ono što se dogodilo s klasičnom pentekostalnom doktrinom. Trudeći se objasniti svoje iskustvo, klasični su pentekostalci razvili doktrinu koju nije moguće održati samo na temelju Pisma. Iako tvrde da primjenjuju hermeneutiku gramatičko-povijesne metode, njihova praksa pokazuje drugačije. ${ }^{13}$

No nisu oni jedini koji nose krivnju. Greška iste prirode događa se na drugoj strani spektra među onim kršćanima koji toliko „uzdižu Riječ“, da niječu djela Duha koja su u njoj opisana. Zato što posjeduju Riječ koja je „dostatna“, cesionisti (oni koji zagovaraju prestanak, tj. obustavu duhovnih darova) niječu ne samo znakove i darove Duha Svetog već i nasušnu potrebu Crkve za njima danas. Da bi se objasnilo kako i zašto je došlo do toga, potrebno bi bilo napraviti odvojeno

13 Ovo je Loderov zaključak u kvalitetno napisanoj disertaciji "An Examination of the Classical Pentecostal Doctrine of the Baptism in the Holy Spirit: In Light of the Pentecostal Position on Sources of Theology." 
istraživanje (ili napisati odvojen članak). I što je onda rješenje ove debate, i postoji li ono uopće?

\section{Praktična primjena doktrine i poticaji iz Pisma}

Jedno od djela Duha Svetog nedvojbeno je i da čuva i vodi Tijelo u ,jedinstvo Duha svezom mira" (Ef 4,3). Prema tomu, je li nešto krivo s iskustvom koje pentekostalci imaju, ili je nešto krivo s djelovanjem Duha? Nijedno od ponuđenog. Ali postoji drugačije objašnjene i jedan drugačiji put, a to je put poniznosti.

Za pentekostalce taj put vodi prema preispitivanju prirode i svrhe njihova doživljaja, na način da ga usklade s kompletnim svjedočanstvom Pisma. Također, tu ulazi i poziv da za teologiju, koju grade na temelju Pisma, teže upotrebljavanju objektivnih metoda interpretacije. Naprotiv, u mjesto slijeđenja takve preporuke, neki, poput Ervina, voljniji su baviti se „hermeneutičkom gimnastikom“ u Efežanima 5,18 ne bi li kako došli do željenog zaključka braneći svoj pogled „jednog krštenja i jednog ispunjenja“. Pa tako on tvrdi: „S obzirom na to da je kontinuirana (durativna) ideja gramatički i kontekstualno poželjnija od iterativnog (ponavljajućeg) smisla glagola „punite se“, iz toga proizlazi da ovaj odjeljak ne uči ponovna ispunjavanja Duhom Svetim, (Ervin 1987, 59).

Povlačenjem doktrinarne crte koja razdvaja spasenje i krštenje u Duhu Svetom, dolazi do ozbiljnoga teološkog problema, koji pak onda dalje vodi u druge negativne stvari, kao što su ekskluzivizam i duhovni ponos. Ako pak doktrinarnu crtu razdvajanja povučemo između krštenja Duhom i ispunjavanja Duhom, teološki problem biva riješen, a s njim bi i popratne komplikacije trebale nestati.

Jedno krštenje Duhom Svetim, a ponavljana ispunjenja (blagoslovi), to je obrazac koji bolje pristaje cjelovitom pogledu na Pismo. Ili, kako to Unger (1944, 239) kaže: „Krštenje u Duhu zahvat je koji se događa jednom i ima trajan učinak, dok je ispunjavanje Duhom kontinuirani proces." Prvi događaj događa se prilikom spasenja, bez nekoga nužnog specifičnog izvanjskog znaka ili potvrde. Taj događaj može ali i ne mora biti trenutno popraćen ispunjenjem Duhom. Ispunjenje Duhom je pak prag čijim se prelaskom definitivno manifestiraju različiti darovi koje Duh daruje kome i kako želi.

Što se tiče pak evanđeoskih ili svih ostalih kršćana, koji naginju više intelektualnom pristupu kršćanstvu, za njih poziv na poniznost ima drugačije konotacije, iako zato nije ništa manje primjenjiv. Premda će se vjerojatno svi brzo složiti da samo mentalno prihvaćanje činjenica i glavnih dogma vjere nije dovoljno, pitanje je koliki će spremno prihvatit poticaj da čeznu ili traže ikakvo iskustvo ili darove. A upravo je to Božji poticaj u Pismu vjernicima; da se kontinuirano ili nanovo ispunjaju Duhom (Ef 5,18). Tako niti oni koji su barem jednom doživjeli to iskustvo pa ga krivo interpretirali, a niti oni koji o tome imaju samo ispravnu 
doktrinu, ali ne i iskustveno znanje, nemaju razloga za ponositost. Svi zajedno mogu, a i trebaju priznati da kontinuirano trebaju Njegovu silu i tada će uistinu biti vođeni Duhom u jedinstvo za koje je Krist molio.

\section{Zaključak}

Krštenje u Duhu je važna, složena i kontroverzna doktrina. Važna je zato što oblikuje vjernikov pogled na spasenje (ordo salutis), posvećenje (bilo da je gledano kao prvi, drugi ili čak treći blagoslov) i razumijevanje normalnoga kršćanskog hoda i iskustva. Kao što Pavao kaže, ako se Duh ne prima isključivo po vjeri, onda je to kontradiktorno i samom Evanđelju milosti. ${ }^{14}$ Krštenje u Duhu složena je doktrina jer uključuje razumijevanje odnosa oba Zavjeta (kontinuitet/diskontinuitet), razumijevanje Crkve (njenu narav i početke) i hermeneutiku općenito (pogotovo razumijevanje žanra povijesnog narativa).

Povezujući zajedno sve te faktore i analizirajući biblijski tekst na način da su događaji stavljeni u ispravni povijesno-spasonosni kontekst, ovaj je članak pokazao da je na početku postavljena teza valjana. Razumijevanje krštenja u Duhu kao neponovljivog događaja, koji je nerazdvojiv od spasenja, jedini je način da se ispravno tretira Evanđelje milosti. Tome u prilog govori i svjedočanstvo i Starog i Novog zavjeta. Čak i temeljni odjeljci (slučajevi u knjizi Djela apostolskih), koje koriste pripadnici teologije "drugog blagoslova“ da bi izgradili svoje uvjerenje, svjedoče za tu istinu.

Usporedni je cilj ovoga članka bio i pokušaj približavanja onih koji dolaze iz različitih pozadina ili tradicija, a pripadaju istoj obitelji po vjeri. Autor ovog članka iskusio je život na obje strane kršćanskog spektra (karizmatsko-pentekostalnog i tradicionalno-evanđeoskog). Provodio je vrijeme među kršćanima koji naglašavaju iskustvo (nadnaravno djelovanje Duha Božjega) i među onima koji naglašavaju intelektualne i doktrinarne aspekte naše vjere (Riječ Božju). Vidio je nepoželjne stvari i imao negativna iskustva za koja se suprotstavljeni 'tabori' međusobno optužuju, ali je isto tako vidio poželjne stvari i imao pozitivna iskustva na obje strane. To je zaista obogatilo njegov kršćanski hod, kako vjeru tako i praksu. Ako ti dobri i pozitivni aspekti dođu zajedno, te i Riječ i Duh dobiju mjesto koje im pripada u našim životima, tada će tijelo Kristovo uistinu rasti „do čovjeka savršena, do mjere uzrasta punine Kristove" $(E f$ 4,13).

14 "Ovo bih samo htio doznati od vas: jeste li primili Duha po djelima Zakona ili po vjeri u Poruku?” (Gal 3,2). 


\section{Bibliografija}

Arrington, French L. 1981. "The Indwelling, Baptism, and Infilling With the Holy Spirit: A Differentation of Terms." Pneuma 3 (1): 1-10.

Brand, Chad. 2004. "The Holy Spirit and Spirit Baptism in Today's Church." U: Chad Brand (ur). Perspectives on Spirit Baptism: Five Views, 1-14. Nashville: B\&H Academic.

Cheung, Tak-Ming. 1996. "Understandings of Spirit-Baptism." Journal of Pentecostal Theology 4 (8): 115-28.

Dayton, Donald W. 1987. “Theological Roots of Pentecostalism”. Metuchen: The Scarecrow Press.

Dunn, James DG. 1993. "Baptism in the Spirit: A Response to Pentecostal Scholarship on Luke-Acts." Journal of Pentecostal Theology 1 (3): 3-27.

Dunning, H. Ray. 2004. "A Wesleyan Perspective on Spirit Baptism." U: Chad Brand (ur). Perspectives on Spirit Baptism, 181-240. Nashville: B\&H Academic.

Ervin, Howard M. 1987. Spirit Baptism: A Biblical Investigation. Peabody: Hendrickson.

Grudem, Wayne A. 2000. Systematic Theology: An Introduction to Biblical Doctrine. Grand Rapids: Zondervan.

Horton, Stanley M. 2004. "Spirit Baptism: A Pentecostal Perspective." U: Chad Brand (ur). Perspectives on Spirit Baptism, 47-104. Nashville: B\&H Academic.

Kaiser, Walter C. 2004. "The Baptism in the Holy Spirit as the Promise of the Father: A Reformed Perspective." U: Chad Brand (ur). Perspectives on Spirit Baptism, 15-46. Nashville: B\&H Academic.

Loder, Allan. 2002. "The Classical Pentecostal Doctrine of Spirit-Baptism: Some Exegetical Considerations." Didaskalia 13: 73-88.

Loder, Allan Thomas. 2000. "An Examination of the Classical Pentecostal Doctrine of the Baptism in the Holy Spirit in Light of the Pentecostal Position on the Sources of Theology." Disertacija, Providence Theological Seminary.

Medved, Goran. 2015. "The Doctrine of Baptism in the Spirit in the Charismatic Movement." Kairos: Evangelical Journal of Theology 9 (2): 171-86.

Unger, Merrill Frederick. 1944. "The Baptism with the Holy Spirit Part 1." Bibliotheca Sacra 101 (402): 232-47.

. 1944a. "The Baptism with the Holy Spirit Part 3." Bibliotheca Sacra 101 (404): 483-99.

Williams, Rodman J. 1990. Renewal Theology. Vol. 2. Grand Rapids: Zondervan. 


\title{
Marko Juriček
}

\section{A Biblical Theology of the Baptism in the Holy Spirit}

\begin{abstract}
This article will discuss the issue of the baptisim of the Holy Spirit: what it is, how is it manifested, and what are its fruits. In the introduction, the problem and the questions pertaining to the Holy Spirit baptism are stated together with the thesis that will be tested. The thesis is that the baptism of the Holy Spirit biblically understood as a unique and unrepeatable event universal to all Christians, which happens instantaneously with salvation (when the believer is placed in Christ and joined to his body) and that this baptism is not marked by any immediate and special outward sign. First, this article will present different views on the doctrine of Holy Spirit baptism with historical developments of the views. Then it will deal with biblical data, focusing on all major passages. Special attention will be given to the Book of Acts, and "the second blessing" theology, which is the crux of the doctrine. Then the relation of hermeneutics and experience will also be discussed. Finally, the conclusion and the practical implications of the baptism of the Holy Spirit and biblical admonishments for the Christian life will be given.
\end{abstract}

